\title{
Diversity and Abundance of Zooplankton in River Aswa in Uganda
}

\author{
Kiggundu V ${ }^{1, *}$, W. Okello ${ }^{1}$, S. V. Matagi ${ }^{2}$, L. Mwebaza-Ndawula ${ }^{1}$ \\ ${ }^{1}$ National Fisheries Resources Research Institute. ${ }^{2}$ SAVIMAXX Ltd. \\ *Corresponding author. @ vkiggundu@hotmail.com
}

\begin{abstract}
Zooplankton community constitutes one of the keystone organisms that are crucial in understanding aquatic ecosystem responses to environmental distresses. The objective of this study was to contribute to the understanding of zooplankton ecological conservation status and assessment of potential impacts of the proposed Hydropower plant on the zooplankton community in River Aswa, Nwoya District, in Uganda. Baseline information on aquatic micro-invertebrate diversity, abundance and distribution along the affected river section was generated. Two copepods and four species of rotifers were recorded. The Intake site had the highest diversity (six species) while Powerhouse had four species. Of the species encountered, Keratella tropica registered the highest abundance-1,025 and 732 individuals $\mathrm{m}^{-2}$ at the Powerhouse and Intake sites, respectively. Total zooplankton densities were comparable with Intake (2,773 individuals $\left.\mathrm{m}^{-2}\right)$ and Powerhouse $\left(2,311\right.$ individuals $\left.\mathrm{m}^{-2}\right)$. The zooplankton taxa do not appear in the IUCN Red List in the Catalogue of Life. Therefore, the proposed construction of a hydropower plant may not pose zooplankton conservation problems.
\end{abstract}

Keywords: Biodiversity, Zooplankton, invertebrates, hydropower, River Aswa.

\section{Introduction}

Zooplankton communities have many ecological values. These include secondary production; occupation of key positions in aquatic food webs, which enables flow of energy from primary producers to higher trophic levels; and serving as indicators of water quality. They also serve as energy recyclers through feeding on decomposing organic materials (Sladecek, 1983; MwebazaNdawula et al., 2005). They are also referred to as 'passive drifters' based on the notion that they are unable to swim against water currents and are transported passively in horizontal plane by the flow field (Wiafe and Frid, 1996). Despite their ecological value, however, compared to North-west and Southern Africa, little attention has been accorded to zooplankton biodiversity in most riverine systems in Eastern Africa (Mavuti and Litterick, 1991; Branstrator et al., 1996; Fernando, 2002, Mwebaza-Ndawula et al., 2005). This has resulted in a general paucity of scientific information on the riverine systems, even though associated fish nutrition is highly dependent on them. To address this gap, this study delved into the diversity and abundance of zooplankton in River Aswa (in Uganda)—to contribute to improved knowledge, assess their 
conservation status and potential impacts of the proposed hydropower plant and implications thereof.

\section{Materials and Methods}

Zooplankton samples were collected from two sites, namely at the proposed Intake site $\left(2.61096^{\circ} \mathrm{N} ; 31.54949 \circ \mathrm{E}\right)$ and Powerhouse $\left(2.61138^{\circ} \mathrm{N} ; 31.53494^{\circ} \mathrm{E}\right)$ (Fig. 1).

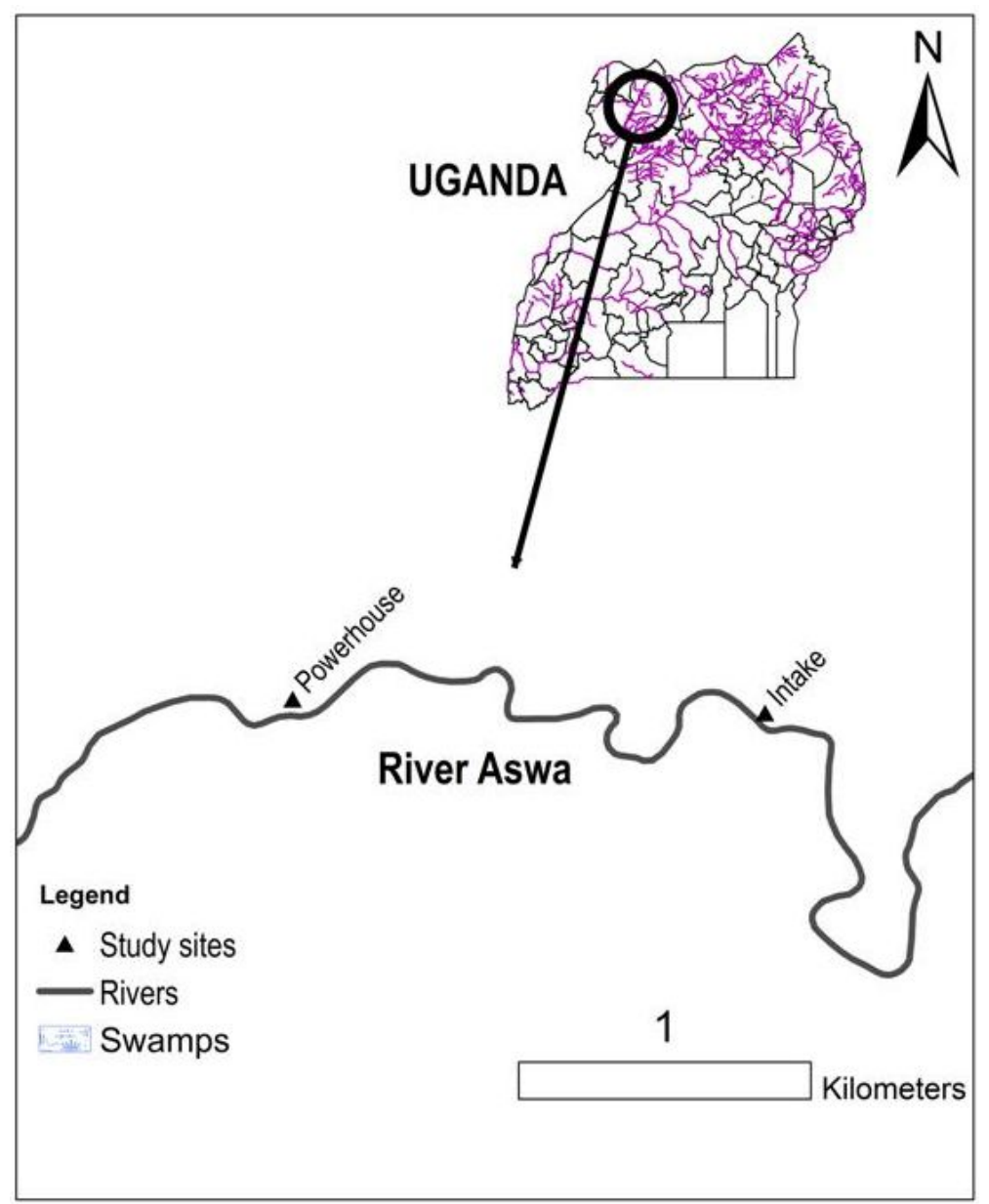

Figure 1. Study sites on the proposed Latoro Small Hydro-Power Project on River Aswa, Uganda.

The sites lie in an area whose residents were displaced previously during a civil war in the early 1980's, and has had minimal human activities that could have degraded the water bodies, giving this portion of the river a relatively pristine environment. A study visit was conducted during the dry month of March 2015, when the river flow was low and detached from the floodplain (Fig. 2), rendering part of the bottom sediment to be exposed to the harsh high temperatures (or drought conditions). 


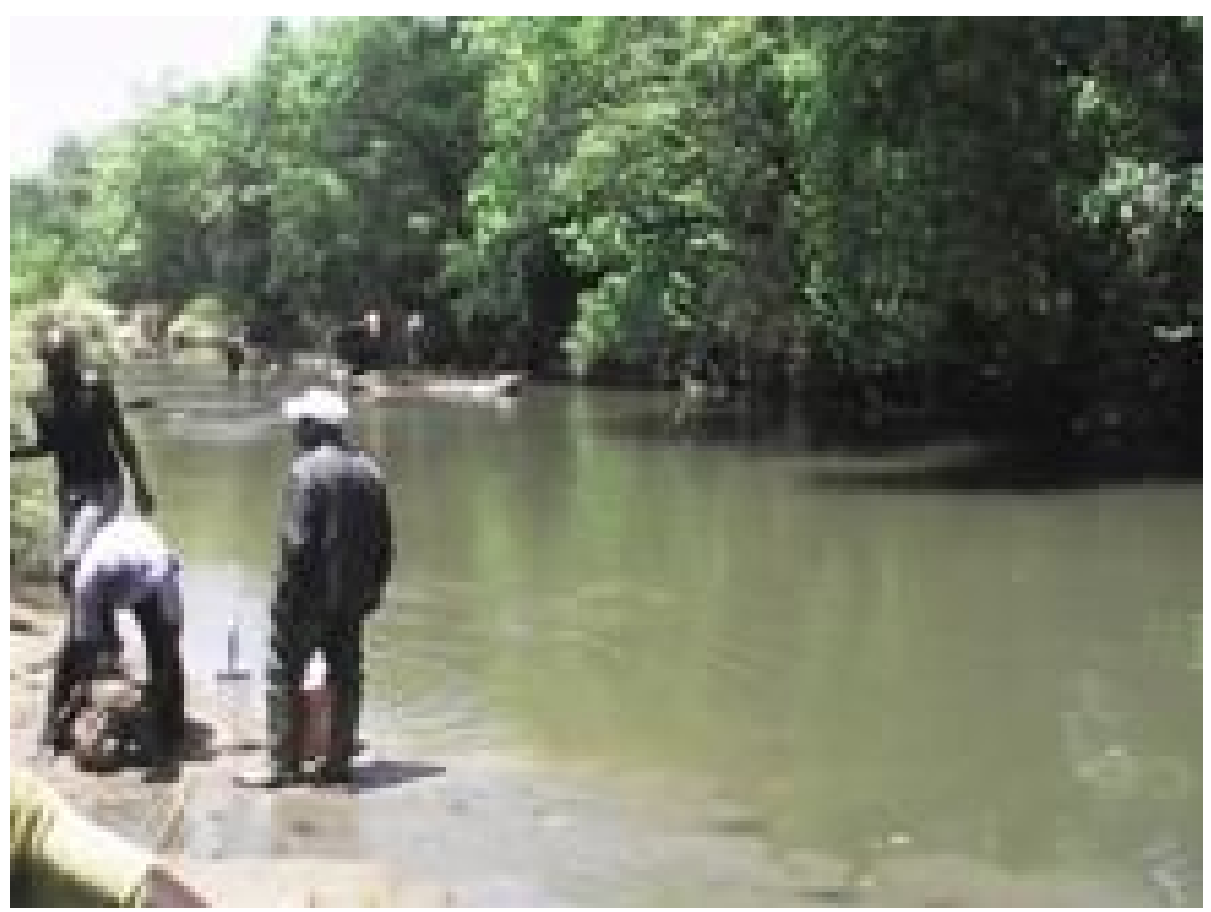

Figure 2. Section of River Aswa with thick acotone zone in the background.

Note the mainstream being detached from the floodplain and exposed bottom rocks in the background.

Other key field observations were the mandatory buffer zone of 100 metres for rivers, specified under the Sixth Schedule of the National Environment (Wetlands; River Banks and Lake Shores Management) Regulations 2000 that was intact. This condition was probably a result of the insecurity in the region over the past 25 years. There was no evidence of commercial fishing activities, except for subsistence fishing reported by residents. However, much of the area was covered by savannah woodlands, composed mainly of Combretum and Terminalia shrubs (Saundry and Fund, 2012).

Samples were collected using a five litre Schindler traps (UWITEC). A total of 10 litres (two hauls) was taken, concentrated through a $53 \mu \mathrm{m}$ sieve, and preserved with $4 \%$ formalin mixed with sucrose (Ngupula, 2013). All samples were taken to the National Fisheries Resources Research Institute (NaFIRRI) laboratories for analysis. In the laboratory, samples were washed over a $53 \mu \mathrm{m}$ sieve to remove the fixative and diluted to a suitable volume depending on the concentration of organisms in each sample. Sub-samples of 2, 5 and $10 \mathrm{ml}$, were taken with a wide bore automatic pipette, from a well agitated sample. Each sub-sample was introduced to a counting chamber and examined under an inverted microscope (HUND WETZLAR) at X100 and X40 magnification for taxonomic analysis and counting, respectively. Species identification was done using available published keys (Sars, 1895; Pennak, 1953, Brooks, 1957, RutnerKolisko, 1974,). Comparison of species richness for zooplankton communities in this section of the river was done with other studied aquatic systems in Uganda and part of South Sudan. 


\section{Results}

The cycloid copepodites contributed high abundances of 1,260 and 855 individuals $\mathrm{m}^{-2}$ for proposed Intake and Powerhouse, respectively; compared to other copepod groups, i.e. nauplius larvae, Tropocyclops confinnis and Mesocyclops sp., which ranged from 0 to 325 individuals $\mathrm{m}^{-2}$ among copepods with respect to the two sites (Table 1). Keratella tropica were the dominant rotiferan species at the two sites; Intake (1025 individuals $\mathrm{m}^{-2}$ ) and Power house (732 individuals $\mathrm{m}^{-2}$ ) compared to other recorded rotifers (Table 1). Copepods were the dominant group in both Intake $\left(1,555\right.$ individuals $\left.\mathrm{m}^{-2}\right)$ and Powerhouse $\left(1,329\right.$ individuals $\left.\mathrm{m}^{-2}\right)$ compared to rotifers with 1,218 and 982 individuals $\mathrm{m}^{-2}$ for Intake and Power house, respectively (Table 1). Total density estimates were comparable between the two sites, that is Intake $\left(2,773\right.$ individuals $\left.\mathrm{m}^{-2}\right)$ and Powerhouse $\left(2,311\right.$ individuals $\left.\mathrm{m}^{-2}\right)$.

Table 1. Zooplankton abundance, species richness and distribution in River Aswa

\begin{tabular}{lcc}
\hline Taxon & Proposed Intake & Proposed Power house \\
\hline Copepoda: & 65 & 0 \\
Mesocyclops sp. & 165 & 149 \\
Tropocyclops confinnis & 1260 & 855 \\
Cyclopoid copepodites & 65 & 325 \\
Nauplius larvae & 2 & 1 \\
Copepoda species richness & 1555 & 1329 \\
Copepoda densities (individuals m & -2 \\
Rotifera: & & \\
Keratella tropica & 1025 & 732 \\
Lecane bulla & 65 & 0 \\
Synchaeta sp. & 49 & 53 \\
Brachionus angularis & 79 & 197 \\
Rotifera species richness & 4 & 3 \\
Rotifera densities (individuals $\mathrm{m}^{-2}$ ) & 1218 & 982 \\
Total species richness & 6 & 4 \\
Total densities (individuals $\mathrm{m}^{-2}$ ) & 2773 & 2311 \\
\hline
\end{tabular}

The river was generally characterised by poor species richness (number of species); six and four at the Intake and Powerhouse, respectively (Table 1). A total of six species were recorded in the two sampled sites (Table 1), compared to Rivers Muyembe (6), Anyau (11), Sio (27), Victoria Nile (26), Gebel Aulia Reservoir (White Nile) (21) and Napoleon Gulf (Lake Victoria) (32) (Table 2). Two copepods (Mesocyclops sp. and Tropocyclops confinnis) and four Rotifers (Keratella tropica, Brachionus angularis, Synchaeta sp. and Lecane bulla) were recorded. The highest diversity of species was at the Intake site with six species, while Powerhouse had four. The only keystone species was Keratella tropica recorded in relatively high densities in both sampled sites (Table 1). 
Table 2. Comparison of zooplankton species composition and distribution with other Rivers in East African region and South Sudan, $\mathrm{P}=$ present.

\begin{tabular}{|c|c|c|c|c|c|c|c|}
\hline Taxon & $\begin{array}{l}\text { River } \\
\text { Aswa }\end{array}$ & $\begin{array}{l}\text { R. Muyembe } \\
\text { (MEMD, 2014) }\end{array}$ & $\begin{array}{l}\text { R. Anyau } \\
\text { (MEMD, } \\
\text { 2015) }\end{array}$ & $\begin{array}{l}\text { River sio } \\
\text { (Gimbo, } \\
\text { 2009) }\end{array}$ & $\begin{array}{l}\text { Victoria Nile } \\
\text { (Mwebaza-Ndawula et } \\
\text { al., 2005) }\end{array}$ & $\begin{array}{l}\text { White Nile (Gebel Aulia } \\
\text { Reservior) (Nuha \& } \\
\text { Schiemer 1993) }\end{array}$ & $\begin{array}{l}\text { Source of Nile } \\
\text { (Vincent et al, } \\
\text { 2012) }\end{array}$ \\
\hline \multicolumn{8}{|l|}{ Copepoda } \\
\hline Mesocyclops sp. & $\mathrm{P}$ & $\mathrm{P}$ & $\mathrm{P}$ & & $\mathrm{P}$ & $\mathrm{P}$ & $\mathrm{P}$ \\
\hline Harpacticoida & & & $\mathrm{P}$ & $\mathrm{P}$ & $\mathrm{P}$ & & \\
\hline Thermocyclops emini & & & & & $\mathrm{P}$ & & $\mathrm{P}$ \\
\hline Thermocyclops incises & & & & $\mathrm{P}$ & $\mathrm{P}$ & & $\mathrm{P}$ \\
\hline T. neglectus & & & $\mathrm{P}$ & & $\mathrm{P}$ & $\mathrm{P}$ & $\mathrm{P}$ \\
\hline $\begin{array}{l}\text { Tropodiaptomus } \\
\text { processifer }\end{array}$ & & & & & & $\mathrm{P}$ & \\
\hline T. kraepelini & & & & & & $\mathrm{P}$ & \\
\hline T. asimi & & & & & & $\mathrm{P}$ & \\
\hline Tropocyclops tenellus & & & & $\mathrm{P}$ & $\mathrm{P}$ & & $\mathrm{P}$ \\
\hline $\begin{array}{l}\text { Tropocyclops } \\
\text { confinnis }\end{array}$ & $\mathrm{P}$ & $\mathrm{P}$ & $\mathrm{P}$ & & $\mathrm{P}$ & & $\mathrm{P}$ \\
\hline $\begin{array}{l}\text { Thermodiaptomus } \\
\text { galeboides }\end{array}$ & & & & & $\mathrm{P}$ & & \\
\hline T. galebi & & & & & & $\mathrm{p}$ & \\
\hline Copepoda species & 2 & 2 & 4 & 3 & 8 & 6 & 6 \\
\hline Cladocera & & & & & & & \\
\hline Alone sp. & & & & & & $\mathrm{P}$ & \\
\hline Bosmina longirostris & & & & $\mathrm{P}$ & $\mathrm{P}$ & $\mathrm{P}$ & $\mathrm{P}$ \\
\hline Ceriodaphnia cornuta & & & & $\mathrm{P}$ & & $\mathrm{P}$ & $\mathrm{P}$ \\
\hline Chydorus sp. & & & $\mathrm{P}$ & & $\mathrm{P}$ & & $\mathrm{P}$ \\
\hline Daphnia barbata & & & & & & $\mathrm{P}$ & \\
\hline Daphnia longispina & & & & & & & $\mathrm{P}$ \\
\hline Daphnia lumholtzi & & & & & & $\mathrm{P}$ & $\mathrm{P}$ \\
\hline Daphnia lumholtzi & & & & $\mathrm{P}$ & & & $\mathrm{P}$ \\
\hline
\end{tabular}




\begin{tabular}{|c|c|c|c|c|c|c|c|}
\hline Taxon & $\begin{array}{l}\text { River } \\
\text { Aswa }\end{array}$ & $\begin{array}{l}\text { R. Muyembe } \\
\text { (MEMD, 2014) }\end{array}$ & $\begin{array}{l}\text { R. Anyau } \\
\text { (MEMD, } \\
\text { 2015) }\end{array}$ & $\begin{array}{l}\text { River sio } \\
\text { (Gimbo, } \\
\text { 2009) }\end{array}$ & $\begin{array}{l}\text { Victoria Nile } \\
\text { (Mwebaza-Ndawula et } \\
\text { al., 2005) }\end{array}$ & $\begin{array}{l}\text { White Nile (Gebel Aulia } \\
\text { Reservior) (Nuha \& } \\
\text { Schiemer 1993) }\end{array}$ & $\begin{array}{l}\text { Source of Nile } \\
\text { (Vincent et al, } \\
\text { 2012) }\end{array}$ \\
\hline $\begin{array}{l}\text { Diaphanosoma } \\
\text { excisum }\end{array}$ & & & & $\mathrm{P}$ & & $\mathrm{P}$ & \\
\hline Moina micrura & & & & & & $\mathbf{P}$ & $\mathbf{P}$ \\
\hline Cladocera species & $\mathbf{0}$ & $\mathbf{0}$ & 1 & 4 & 2 & 7 & 7 \\
\hline Ascomorpha sp. & & & & $\mathrm{P}$ & & & $\mathrm{P}$ \\
\hline Asplanchna sp. & & & & & $\mathrm{P}$ & $\mathrm{P}$ & $\mathrm{P}$ \\
\hline Brachionus angularis & $\mathrm{P}$ & $\mathrm{P}$ & $\mathrm{P}$ & & $\mathrm{P}$ & & $\mathrm{P}$ \\
\hline B. bidentatus & & & & $\mathrm{P}$ & & & $\mathrm{P}$ \\
\hline B. calyciflorus & & & & & & & $\mathrm{P}$ \\
\hline B. caudatus & & & & & $\mathrm{P}$ & & \\
\hline B. dimidiates & & & & & $\mathrm{P}$ & & \\
\hline B. falcatus & & & & $\mathrm{P}$ & $\mathrm{P}$ & & $\mathrm{P}$ \\
\hline B. forficula & & & & & $\mathrm{P}$ & & $\mathrm{P}$ \\
\hline B. patulus & & & & & & & $\mathrm{P}$ \\
\hline B. plicatilis & & & & & & & $\mathrm{P}$ \\
\hline Brachionus sp. & & & & $\mathrm{P}$ & & $\mathrm{P}$ & \\
\hline Cephalodella gibba & & & & $\mathrm{P}$ & & & \\
\hline Collotheca trilobata & & & & $\mathrm{P}$ & & & \\
\hline Dipleuchlanis & & & & $\mathrm{P}$ & & & \\
\hline propatula & & & & & & & \\
\hline Euclanis sp. & & & & & $\mathrm{P}$ & & $\mathrm{P}$ \\
\hline Filinia longiseta & & & $\mathrm{P}$ & & $\mathrm{P}$ & $\mathrm{P}$ & $\mathrm{P}$ \\
\hline F. opoliensis & & & & & & $\mathrm{P}$ & \\
\hline Hexarthra sp. & & & & & $\mathrm{P}$ & $\mathrm{P}$ & $\mathrm{P}$ \\
\hline Keratella cochlearis & & & & & $\mathrm{P}$ & $\mathrm{P}$ & $\mathrm{P}$ \\
\hline Keratella quadrata & & & & $\mathrm{P}$ & & & \\
\hline K. tropica & $\mathrm{P}$ & $\mathrm{P}$ & $\mathrm{P}$ & & $\mathrm{P}$ & $\mathrm{P}$ & $\mathrm{P}$ \\
\hline
\end{tabular}




\begin{tabular}{|c|c|c|c|c|c|c|c|}
\hline Taxon & $\begin{array}{l}\text { River } \\
\text { Aswa }\end{array}$ & $\begin{array}{l}\text { R. Muyembe } \\
\text { (MEMD, 2014) }\end{array}$ & $\begin{array}{l}\text { R. Anyau } \\
\text { (MEMD, } \\
\text { 2015) }\end{array}$ & $\begin{array}{l}\text { River sio } \\
\text { (Gimbo, } \\
\text { 2009) }\end{array}$ & $\begin{array}{l}\text { Victoria Nile } \\
\text { (Mwebaza-Ndawula et } \\
\text { al., 2005) }\end{array}$ & $\begin{array}{l}\text { White Nile (Gebel Aulia } \\
\text { Reservior) (Nuha \& } \\
\text { Schiemer 1993) }\end{array}$ & $\begin{array}{l}\text { Source of Nile } \\
\text { (Vincent et al, } \\
\text { 2012) }\end{array}$ \\
\hline Lecane bulla & $\mathrm{P}$ & $\mathrm{P}$ & $\mathrm{P}$ & & $\mathrm{P}$ & & $\mathrm{P}$ \\
\hline Macrochaetus collinsi & & & & $\mathrm{P}$ & & & \\
\hline Macrochaetus & & & & $\mathrm{P}$ & & & \\
\hline longipes & & & & & & & \\
\hline Monommata & & & & $\mathrm{P}$ & & & \\
\hline appendiculata & & & & & & & \\
\hline Monommata sp. & & & & $\mathrm{P}$ & & & \\
\hline Mytilina sp. & & & & $\mathrm{P}$ & & & \\
\hline Mytilina ventralis & & & & $\mathrm{P}$ & & & \\
\hline Notholca sp. & & & & $\mathrm{P}$ & & & \\
\hline Platyas quadricoris & & & & & $\mathrm{P}$ & & $\mathrm{P}$ \\
\hline Polyarthra sp. & & & & $\mathrm{P}$ & & & \\
\hline Polyarthra vulgaris & & & & $\mathrm{P}$ & $\mathrm{P}$ & & $\mathrm{P}$ \\
\hline Synchaeta sp. & $\mathrm{P}$ & $\mathrm{P}$ & $\mathrm{P}$ & & $\mathrm{P}$ & & $\mathrm{P}$ \\
\hline Trichoderma & & & $\mathrm{P}$ & & $\mathrm{P}$ & $\mathrm{P}$ & $\mathrm{P}$ \\
\hline $\begin{array}{l}\text { cylindrica } \\
\text { Trichotria sp. }\end{array}$ & & & & $\mathrm{P}$ & & & \\
\hline Trichotria pocillum & & & & $\mathrm{P}$ & & & \\
\hline Trichotria tetractis & & & & $\mathrm{P}$ & & & \\
\hline Rotifera Species & 4 & 4 & 6 & 20 & 16 & 8 & 19 \\
\hline $\begin{array}{l}\text { Total species } \\
\text { richness }\end{array}$ & 6 & 6 & 11 & 27 & 26 & 21 & 32 \\
\hline
\end{tabular}


Copepods were higher than rotifers, contributing 56 and 58\% relative abundance for Intake and Powerhouse, respectively; compared to rotifers with Intake (44\%) and Powerhouse (42\%) (Fig. 3). The trend differed in terms of species richness, with rotifers dominating by 67 and $75 \%$ compared to copepods 33 and 25\% for intake and Powerhouse, respectively (Fig. 3).

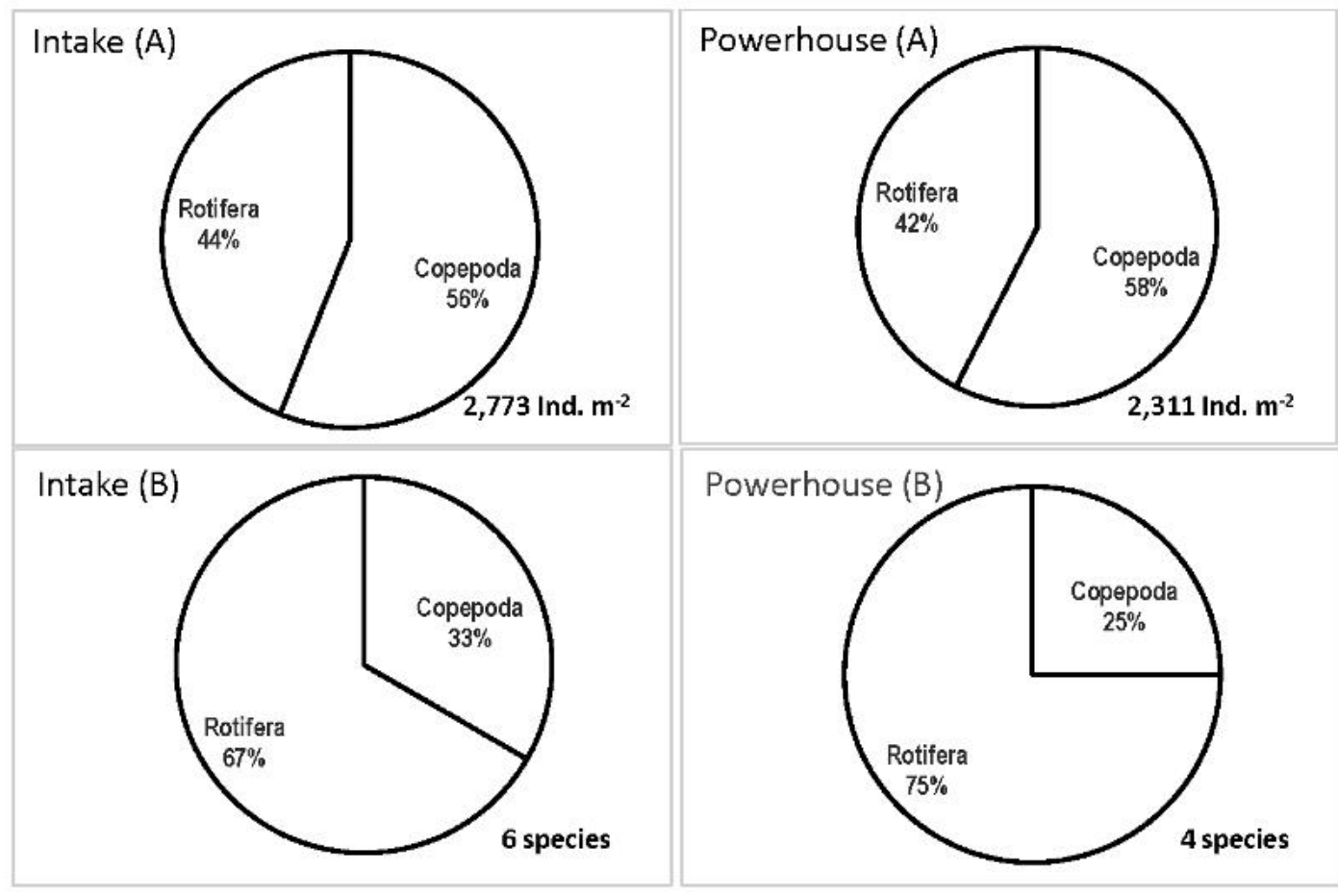

Figure 3. Relative abundance (A) and species richness (B) for Intake and Power house sites, River Aswa.

\section{Discussion}

Poor species richness and abundance patterns for zooplankton in R. Aswa, is a trend typical for most riverine communities (especially mainstream), which is a dynamism of hydrological regime and seasonality (Nuha and Schiemer, 1993; Basu and Pick, 1996; Baranyi et al., 2002; Susanne et al., 2003; Mwebaza-Ndawula et al., 2005; Gimbo, 2009). It has been revealed that Plankton communities in river systems are important when residence time allows sufficient duration for growth and reproduction (Basu and Pick, 1996; Baranyi, 2002). This trend of low species richness and abundance in River Aswa is similar to results observed in Rivers Muyembe, Sirimityo and Mbigi, and Anyau (MEMD, 2014; MEMD, 2015). However, comparison of species richness for zooplankton communities with other studied aquatic systems in Uganda and part of South Sudan, confirmed the very low species richness of this section of the river (Nuha \& Schiemer 1993; Mwebaza-Ndawula et al., 2005; Gimbo, 2009 Unpublished; Vincent et al., 2012). Studies elsewhere have also confirmed that zooplankton biomass and abundance in rivers is much lower than in lakes of comparable nutrient and chlorophyll concentrations (Thorp et al. 1994; Basu and Pick 1996; Pace et al., 1992). The conditions that determine such 
trends are mainly variations in flow regimes and physical habitats, channel shape, sediment transport, water temperature and chemistry, and food items (like algae) (Poff and Hart, 2002).

At the time of sampling, water level for this river had drastically dropped as evidenced from the exposed lower river bed, disconnected from the floodplains which are known to recharge the mainstream with various zooplankton organisms (Basu and Pick, 1996; Gimbo, 2009; Baranyi et al., 2002). Goździejewska et al. (2016) compared diversity of zooplankton in two successive phases; potamophase as opposed to limnophase and the former had higher diversity due to hydrological connectivity. The floodplain causes gross changes in flow regimes by slowing water movement, thus increasing the water resident time that greatly favour feeding and productivity of zooplankton and harbouring reasonable amount of nutrients to facilitate production of food items for zooplankton.

Dams of whatever size, are known to impact river systems by altering key parameters like flow regimes, physical habitats, water temperature and changes in population of food items (algae) and riparian vegetation (Poff and Hart, 2002); which determine the relative abundance and distribution of different zooplankton organisms. The physical structures such as weirs create distinct physical and ecological conditions relative to free-flowing lotic reaches and influence aquatic biodiversity (especially zooplankton) in streams/rivers. Thus, basing on this principle, the dam may have great impacts on the zooplankton communities by turning the lotic system to lentic, especially upstream. It is, however, difficult at present to list out the particular organisms of concern, being that most of the observed taxa have not yet been assessed for the IUCN Red List in the Catalogue of Life. The lentic conditions may have increased preypredator interaction, and enhanced evaporation that may change the chemistry of water. Studies in China have shown the existence of small dams having a significant effect on the zooplankton community (Shuchan et al., 2008), with long periods of drought (dry seasons) showing effects of the dam on potamoplankton being more pronounced due to increased evaporation; while the downfall or the connectivity of channel appear to decrease the effect of small hydropower plants on riverine zooplankton. The proposed Latoro SHPP may experience some of these effects given that it lies in the area characterised with very long dry spells and high temperatures.

In summary, the environment concerns (impacts) and mitigation measures of this proposed Hydropower project are likely to include;

Changes in flow regimes due to diversion which will influence retention time (lotic to lentic), creating adverse impacts on the zooplankton communities, including enhanced predation upstream; this can be mitigated by maintaining a mandatory discharge while production during adverse dry season should be checked as it helps in maintaining acceptable flow rates/regimes for the mainstream channel.

Habitat loss due to silting during construction and agricultural practices downstream interfering with critical habitats for aquatic invertebrates. Construction during heavy rains should be checked/halted as water logged soils are easily eroded. Sensitisation of communities on good agricultural practices and reduction of soil erosion by planting native trees and grass immediately after construction, together with promotion of tree planting within the river catchment may help to mitigate this concern.

Water quality deterioration may be due to the material used in construction and submerged vegetation upstream might pollute or have negative effect on physico-chemical parameters during the biodegradation and might also increase levels of contaminants (like heavy metals), which may impact on aquatic organisms eliminating less tolerant like the copepods while others like rotifers (Brachionids) may increase. Planning and installing sediment retention devices and contaminant free material are highly recommended during construction. 


\section{Acknowledgement}

This work formed part of the Ten proposed Small Hydro-Power Projects (SHPPs) led by the Ministry of Energy and Mineral Development in Uganda under the support of the World Bank. The Director National Fisheries Resources Research Institute (NaFIRRI) is acknowledged for permission to use NaFIRRI Laboratories for sample analyses. Posch and Partners Consulting Engineers of Austria provided the logistical support during field sampling. The comments of two anonymous reviewers helped in improving the quality of the manuscript.

\section{References}

Baranyi, C., Hein, T., Holarek, C., Keckeis, S. \& Schiemer, F. 2002. Zooplankton biomass and community structure in a Danube River floodplain system: effects of hydrology. Freshwater Biology, 47, 473-482.

Basu, B. K. \& Pick, F. R. 1996. Factors regulating phytoplankton and zooplankton biomass in temperate rivers. Limnology. Oceanography, 41, 1572-1577.

Branstrator, D. K., Lehman, J. T. \& Mwebaza-Ndawula, L. 1996. Zooplankton dynamics of Lake Victoria. In: Johnson, T. C. \& Odada, E. O. (Eds). The limnology, Climatology and Paeoclimatology of East African Lakes. Amsterdam: Cordon and Breach Publishers.

Brooks, J. L. 1957. The systematics of North American Daphnia. Memoirs of the Connecticut academy of Arts and Sciences, 13, 1-18.

Fernando, C. H. 2002. A Guide to Tropical Freshwater Zooplankton. Identification, Ecology and Impact on Fisheries, Leiden: The Netherlands, Backhuys Publishers.

Gimbo, R. 2009. Spatial variability of zooplankton along a section of River Sio under different habitat conditions. MSc thesis ES 09.31, UNESCO-Institute for Water Education.

Goździejewska, A., Glińska-Lewczuk, K., Obolewski, K., Grzybowski, M., Kujawa, R., Lew, S. \& Grabowska, M. 2016. Effects of lateral connectivity on zooplankton community structure in floodplain lakes. Hydrobiologia, 774, 7-21.

Mavuti, K. M. \& Litterick, M. R. 1991. Composition, distribution and ecological role of zooplankton community in Lake Victoria, Kenya waters. Verbandlungen des Internationalen Verein Limnologie, 24, 1117 - 1122.

MEMD (2014). Environmental and Social Impact Assessment of Muyembe Mini Hydropower Project, Kakomoronoi Village, Kapsoyoyi Parish, Chepterech Sub County, Kapchorwa District; Rock View and Sangaris Villages, Kamu Parish, Kamu Sub County and Mbigi Parish, Bulegeni Sub County, Bulambuli District. Ministry of Energy and Mineral Development, Kampala by Posch and Partners of Austria Consultancy Report.

MEMD (2015). Environmental and Social Impact Assessment of Okulacere Mini Hydropower Project, on River Anyau, Odari Village, Ndaapi Parish, Mugo Sub-county, Terego County in Arua District. Ministry of Energy and Mineral Development, Kampala by Posch and Partners of Austria Consultancy Report.

Mwebaza-Ndawula, L., Sekiranda, S. B. K. \& Kiggundu, V. 2005. Variability of zooplankton community along a section of the Upper Victoria Nile, Uganda. African Journal of Ecology 251257.

NaFIRRI 2006. Environmental and Social Impact Assessment (ESIA) of the Bujjagali Hydropower Project (BHPP), Uganda Fisheries Component. Prepared by R. J. Burnside International Limited. 
Ngupula, G. W. 2013. How does increased eutrophication and pollution in the Lake Victoria waters impacts zooplankton? Journal of Environment and Ecology, 4, 151-164.

Nuha, H. S. \& Schiemer, F. 1993. The seasonality of zooplanktivorous fish in an African reservoir (Gebel Aulia Reservoir, White Nile, Sudan). Hydrobiologia, 250, 173-185.

Pennak, R. W. 1953. Fresh-water invertebrates of the United States, New York, John Wiley \& Sons.

Poff, N. L. \& Hart, D. D. 2002. How Dams Vary and Why It Matters for the Emerging Science of Dam Removal. BioScience, 52, 659-668.

Rutner-Kolisko, A. 1974. Planktonic rotifers: Biology and taxonomy, Biological Station Lunz of the Austrian Academy of Science. E. Schweizerbart'sche Verlagsbuchhandlung.

Sars, G. O. 1895. An account of the Crustacea of Norway, Christiania and Copenhagen Alb. Cammermeyer Forlag.

Saundry, P. \& Fund, W. 2012. Achwa River, Uganda [Online]. http://www.eoearth.org/view/article/149811. [Accessed 30th March 2015].

Shuchan, Z., Tao, T., Naicheng, W., Xiaocheng, F. \& Qinghua, C. 2008. Impacts of a Small Dam on Riverine Zooplankton. Internat. Rev. Hydrobiol., 93, 297 - 311.

Sladecek, V. 1983. Rotifers as indicators of water quality. Hydrobiologia, 100, 169-201.

Susanne, K., Baranyi, C., Hein, T., Holarek, C., Riedler1, P. \& Schiemer, F. 2003. The significance of zooplankton grazing in a floodplain system of the River Danube. Journal of Plankton Research, 25, 243-253.

Wiafe, G. \& Frid, C. L. J. 1996. Short-term temporal variation in coastal zooplankton communities: the relative importance of physical and biological mechanisms. Journal of Plankton Research, 18, 1485 - 1501. 